\section{Trends in self-reported arterial hypertension in Brazilian adults: an analysis of data from the Brazilian National Household Sample Survey, 1998-2008}

\author{
Tendência temporal de hipertensão arterial \\ autorreferida em adultos: uma análise da \\ Pesquisa Nacional por Amostra de Domicílios, \\ 1998-2008
}

\author{
Ludmila Correa Muniz 1 \\ Andreia Morales Cascaes 1 \\ Fernando César Wehrmeister 1 \\ Jeovany Martínez-Mesa 1 \\ Aluisio J. D. Barros 1 \\ Ana Maria Baptista Menezes 1
}

\author{
1 Programa de Pós-graduação \\ em Epidemiologia, \\ Universidade Federal de \\ Pelotas, Pelotas, Brasil. \\ Correspondence \\ L. C. Muniz \\ Programa de Pós-graduação \\ em Epidemiologia, \\ Universidade Federal de \\ Pelotas. \\ Rua Marechal Deodoro 1160, \\ 3 o andar, Pelotas, $R S$ \\ 96020-220, Brasil. \\ ludmuniz@yahoo.com.br
}

\section{Abstract}

This study investigated the time trend in selfreported arterial hypertension from 1998 to 2008 in individuals older than 20 years in Brazil. Data were analyzed on prevalence of hypertension from the National Household Sample Survey (PNAD) for the years 1998, 2003, and 2008. The analysis considered the sampling complexity and included 203,419, 238,591, and 257,816 individuals in the years 1998, 2003, and 2008, respectively. The time trend in hypertension was analyzed by sex, family income, geographic regions of Brazil, and area of residence (urban versus rural), and the prevalence rates were adjusted for age. Prevalence of self-reported hypertension was 12.5\% in 1998, 13\% in 2003, and $13.9 \%$ in 2008, with an annual increase of $1.07 \%$. The highest increases occurred in the Southeast Region (1.41\%), in men (1.82\%), and in urban areas (1.15\%). The study showed a rise in the prevalence of self-reported hypertension in all income brackets and with increasing age. Knowledge of the prevalence of hypertension is essential for backing activities to prevent and control the problem, especially among the more vulnerable subgroups.

Hypertension; Adult; Chronic Disease; Prevalence

\section{Introduction}

Systemic arterial hypertension (SAH) is a risk factor for cardiovascular, cerebrovascular, and renal diseases and accounts for some $40 \%$ of deaths due to stroke and $25 \%$ of deaths from coronary artery disease $1,2,3$. SAH affects more than 30 million Brazilians, with an annual treatment cost of approximately US\$ 398.9 million for the public Brazilian Unified National Health System (SUS) and US\$272.7 million for the private healthcare system, representing $1.11 \%$ of overall healthcare expenditures 4 . Negative effects have also been reported on quality of life for individuals with $\mathrm{SAH}$, including physical, functional, emotional, and mental problems and various forms of pain 5 .

The detection, treatment, and control of systemic arterial hypertension are essential for the prevention and management of health outcomes related to the disease. Population-based surveys have thus been conducted in various countries to monitor trends in arterial hypertension (measured or self-reported), showing important increases in its prevalence. A study in Mexico based on three nationwide health surveys showed that prevalence of arterial hypertension increased from $23.8 \%$ in 1993 to $43.2 \%$ in 2006 6. In Brazil, the Telephone Survey for Surveillance of Risk and Protective Factors for Chronic Non-Communicable Diseases (VIGITEL) showed that self-reported arterial hypertension increased evenly and 
significantly in the 27 State capitals included in the study, varying from $21.5 \%$ to $24.4 \%$ from 2006 to 2009 7. Developed countries like Switzerland, Canada, and the United States have also shown increases in the prevalence of self-reported arterial hypertension 8,9,10,11,12.

The National Household Sample Survey (PNAD) provides representative data on self-reported arterial hypertension in the major geographic regions, States, and some metropolitan areas of Brazil. Although self-reported measures are subject to classification errors, Brazilian and international studies have shown that selfreported arterial hypertension appears to be a valid indicator for estimating prevalence of the disease 13,14,15,16. Monitoring the prevalence of systemic arterial hypertension, as assessed in the PNAD, helps identify the distribution of the disease and thus supports the implementation of appropriate health measures. In this context, the current study aimed to describe the time trend in the prevalence of self-reported arterial hypertension in Brazil, in adults twenty years and older, according to demographic and socioeconomic characteristics, using data from the PNAD for the years 1998, 2003, and 2008.

\section{Methods}

The study was conducted with data from the health supplements included in the PNAD in 1998,2003 , and 2008. PNAD is a survey conducted by the Brazilian Institute of Geography and Statistics (Instituto Brasileiro de Geografia e Estatística - IBGE) and whose objective is to furnish basic information on the country's socioeconomic development. The survey has been conducted every five years since 1998 and has included a health supplement that provides a five-year historical series with national population-based information on health conditions and access, utilization, and financing of health services in Brazil 17.

The sampling plan in the PNAD is conducted in up to three stages (municipalities or counties, census tracts, and households), thereby guaranteeing the sample's representativeness for the country, geographic regions, States, and some metropolitan areas 18. The sample consisted of $344,975,384,834$, and 391,868 individuals in 1998, 2003, and 2008, respectively. Additional information on methodology and sampling can be found on the IBGE website 19,20.

The current study population consisted of individuals 20 years of age or over. The question "Has a physician or other health professional ever said (...) that you have arterial hypertension (high blood pressure)?" was used to estimate the prevalence of self-reported arterial hypertension for each year. The variable was used dichotomously, as a "yes" or "no" answer.

Prevalence of self-reported arterial hypertension was analyzed according to sex, age, monthly per capita family income, major geographic regions, and area of residence (urban versus rural). Age was categorized in brackets: 20-29, 30-39, 40-49, 50-59, and 60 years or older. Monthly per capita family income was measured in reais and later categorized in income quintiles for Brazil. The area of residence variable was dichotomized as "urban" (city or town in an urbanized area, city or town in a non-urbanized area, and isolated urban area) and "rural" (rural cluster as an urban extension, isolated rural cluster or village, isolated rural cluster - nucleus, isolated rural cluster - other clusters and rural areas other than rural clusters).

The databases were obtained from the IBGE. Data were analyzed in the Stata software, version 11.0 (Stata Corp., College Station, USA), using the svyset command to define the sampling weights and clusters and the svy prefix for all the analyses, given the complexity of the sampling process. Prevalence rates for self-reported arterial hypertension were estimated for Brazil and its geographic regions, as well as annual percentage ranges. This information was also stratified by area of residence and sex. The prevalence rates for systemic arterial hypertension were adjusted for age.

The mean annual percentage variation was calculated using the prevalence values observed in 1998 and 2008. The total percentage variation was calculated, and the mean annual variation was estimated as its $10^{\text {th }}$ root:

$$
\sqrt[10]{1+\left(\frac{\left(\mathrm{p}_{2008}-\mathrm{p}_{1998}\right)}{\mathrm{p}_{1998}}\right)}
$$

where $\mathrm{p}_{1998}$ and $\mathrm{p}_{2008}$ are the prevalence rates calculated for the years 1998 and 2008, respectively. The statistical test used to verify the time trend was the Wald test for linear trend.

\section{Results}

The current study only evaluated individuals twenty years or older, with information on selfreported arterial hypertension, totaling 203,419, 238,591 , and 257,816 individuals in 1998, 2003, and 2008, respectively.

Table 1 shows the sample's characteristics for each year of the PNAD. In all three years there was a slight predominance of females and young adults (20-29 years). As for the geographic region 
Demographic and socioeconomic characteristics of the sample. National Household Sample Survey (PNAD), Brazil, 1998-2008.

\begin{tabular}{|c|c|c|c|}
\hline \multirow[t]{2}{*}{ Variables } & $1998(n=203,419)$ & $2003(n=238,591)$ & $2008(n=257,816)$ \\
\hline & $\%$ * & $\%$ * & $\%$ * \\
\hline \multicolumn{4}{|l|}{ Sex } \\
\hline Male & 47.7 & 47.5 & 47.5 \\
\hline Female & 52.3 & 52.5 & 52.5 \\
\hline \multicolumn{4}{|l|}{ Age (years) } \\
\hline $20-29$ & 27.8 & 28.1 & 26.0 \\
\hline $30-39$ & 25.0 & 23.5 & 22.3 \\
\hline $40-49$ & 19.6 & 19.7 & 20.1 \\
\hline $50-59$ & 12.8 & 13.4 & 14.9 \\
\hline$\geq 60$ & 14.8 & 15.3 & 16.7 \\
\hline \multicolumn{4}{|l|}{ Area of residence } \\
\hline Urban & 82.2 & 85.6 & 85.0 \\
\hline Rural & 17.8 & 14.4 & 15.0 \\
\hline \multicolumn{4}{|c|}{ Geographic Region } \\
\hline North & 4.4 & 5.3 & 7.1 \\
\hline Northeast & 26.4 & 26.4 & 26.5 \\
\hline Southeast & 46.4 & 45.8 & 44.2 \\
\hline South & 15.9 & 15.5 & 15.0 \\
\hline Central-West & 6.9 & 7.0 & 7.2 \\
\hline \multicolumn{4}{|c|}{ Income in quintiles } \\
\hline 1 (lowest) & 20.7 & 20.7 & 20.1 \\
\hline 2 & 19.3 & 19.5 & 20.2 \\
\hline 3 & 20.7 & 20.8 & 19.8 \\
\hline 4 & 19.3 & 19.2 & 20.0 \\
\hline 5 (highest) & 20.0 & 19.8 & 19.9 \\
\hline
\end{tabular}

* Adjusted for cluster effect and sampling weight.

and area of residence, the majority lived in the Southeast region and in urban areas in all three years, while there was an increase from 1998 to 2008 in the proportion of individuals living in the North of Brazil. The year 2008 showed a lower proportion of individuals from the lowest income quintile as compared to 1998.

Table 2 describes the prevalence of selfreported arterial hypertension and the annual variation for Brazil and its geographic regions, according to sex and area of residence. At any rate, from 1998 to 2008 there was an increase in the prevalence of arterial hypertension in Brazil as a whole and in all the geographic regions, except for the North and Central-West. Except for the North (for males) and the North and CentralWest (for females), all the other regions and the country as a whole showed an increase in the prevalence of SAH in both sexes from 1998 to 2008. In Brazil and in all the regions, the prevalence of self-reported arterial hypertension was always higher among women; however, the annual variation was always higher in men, reaching some $2 \%$ per year in the South and Southeast. For Brazil as a whole, the annual increase was lower in the rural as compared to urban areas $(0.7 \%$ and $1.2 \%$, respectively). In the rural areas in the South and Southeast, the annual increases in the prevalence of arterial hypertension were $1 \%$ and $1.6 \%$, respectively.

Figure 1 shows the trends in the overall and sex-specific prevalence of self-reported systemic arterial hypertension according to age. From 20 to 49 years of age there was a trend towards stability in prevalence of arterial hypertension, with an upward trend in both sexes starting at 50 years. Prevalence of systemic arterial hypertension was higher in women than in men, especially from the 40-49-year bracket upward.

Figure 2 shows the trends in the overall and sex-specific prevalence of self-reported arterial hypertension according to per capita income 
Prevalence of self-reported arterial hypertension and annual variation for Brazil and regions according to sex and area of residence. National Household Sample Survey (PNAD), Brazil, 1998-2008.

\begin{tabular}{|c|c|c|c|c|c|}
\hline & \multicolumn{3}{|c|}{ Prevalence of self-reported arterial hypertension (\%) * } & \multirow{2}{*}{$\begin{array}{c}\text { Annual } \\
\text { variation (\%) }\end{array}$} & \multirow[t]{2}{*}{ p-value ** } \\
\hline & 1998 & 2003 & 2008 & & \\
\hline \multicolumn{6}{|l|}{ Total } \\
\hline Brazil & 12.5 & 13.0 & 13.9 & +1.07 & $<0.001$ \\
\hline North & 12.2 & 11.3 & 11.8 & -0.33 & 0.063 \\
\hline Northeast & 12.2 & 12.2 & 13.3 & +0.87 & $<0.001$ \\
\hline Southeast & 12.6 & 13.6 & 14.5 & +1.41 & $<0.001$ \\
\hline South & 12.5 & 12.9 & 13.9 & +1.07 & $<0.001$ \\
\hline Central-West & 13.4 & 13.9 & 14.0 & +0.44 & 0.127 \\
\hline \multicolumn{6}{|l|}{ Men } \\
\hline Brazil & 9.6 & 10.1 & 11.5 & +1.82 & $<0.001$ \\
\hline North & 8.8 & 8.6 & 9.4 & +0.66 & 0.249 \\
\hline Northeast & 8.6 & 8.9 & 10.3 & +1.82 & $<0.001$ \\
\hline Southeast & 10.1 & 10.7 & 12.4 & +2.07 & $<0.001$ \\
\hline South & 9.6 & 10.2 & 11.7 & +2.00 & $<0.001$ \\
\hline Central-West & 10.3 & 11.1 & 11.6 & +1.20 & 0.003 \\
\hline \multicolumn{6}{|l|}{ Women } \\
\hline Brazil & 15.3 & 15.8 & 16.2 & +0.57 & $<0.001$ \\
\hline North & 15.5 & 14.1 & 14.3 & -0.80 & 0.002 \\
\hline Northeast & 15.6 & 15.5 & 16.0 & +0.25 & 0.035 \\
\hline Southeast & 14.9 & 16.2 & 16.5 & +1.03 & $<0.001$ \\
\hline South & 15.2 & 15.5 & 16.1 & +0.58 & 0.003 \\
\hline Central-West & 16.5 & 16.8 & 16.5 & 0.00 & 0.384 \\
\hline \multicolumn{6}{|l|}{ Urban areas } \\
\hline Brazil & 12.4 & 13.1 & 13.9 & +1.15 & $<0.001$ \\
\hline North & 11.9 & 11.2 & 12.0 & +0.08 & 0.538 \\
\hline Northeast & 12.8 & 12.7 & 13.7 & +0.68 & $<0.001$ \\
\hline Southeast & 12.2 & 13.3 & 14.2 & +1.53 & $<0.001$ \\
\hline South & 12.3 & 13.0 & 13.8 & +1.16 & $<0.001$ \\
\hline Central-West & 13.2 & 13.9 & 14.0 & +0.59 & 0.120 \\
\hline \multicolumn{6}{|l|}{ Rural areas } \\
\hline Brazil & 13.0 & 12.9 & 14.0 & +0.74 & $<0.001$ \\
\hline North *** & - & - & 11.5 & - & - \\
\hline Northeast & 11.8 & 11.6 & 12.7 & +0.74 & $<0.001$ \\
\hline Southeast & 14.4 & 15.3 & 16.8 & +1.55 & $<0.001$ \\
\hline South & 13.5 & 12.9 & 14.9 & +0.99 & $<0.001$ \\
\hline Central-West & 14.3 & 14.1 & 14.1 & -0.14 & 0.994 \\
\hline
\end{tabular}

* Age-adjusted prevalence rates;

** Wald test for linear trend;

*** In the Northern Region, in the years 1998 and 2003, the PNAD only considered the State of Tocantins in defining the rural area.

quintiles. There is a clear upward trend in the prevalence rates for self-reported systemic arterial hypertension in all the income quintiles, except for women in the third quintile. In all the income groups, the prevalence was higher among women than men.

\section{Discussion}

Prevalence of self-reported arterial hypertension increased from 1998 to 2008 in Brazil and in its various geographic regions (1.07\% per year). Although the estimated prevalence for all three 


\section{Figure 1}

Trend in prevalence of self-reported arterial hypertension according to age, for the total sample and stratified by sex. National Household Sample Survey (PNAD), Brazil, 1998-2008.

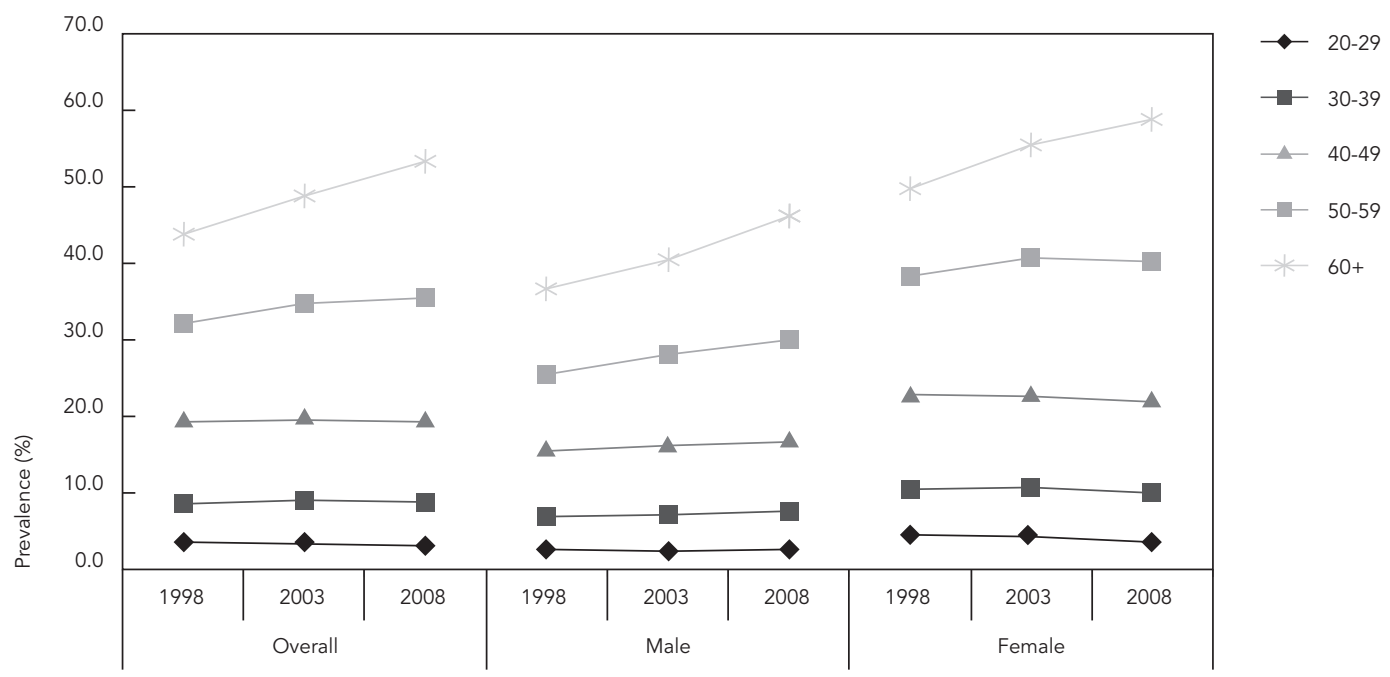

\section{Figure 2}

Trend in prevalence of self-reported arterial hypertension according to per capita income quintiles, for the total sample and stratified by sex. National Household Sample Survey (PNAD), Brazil, 1998-2008.

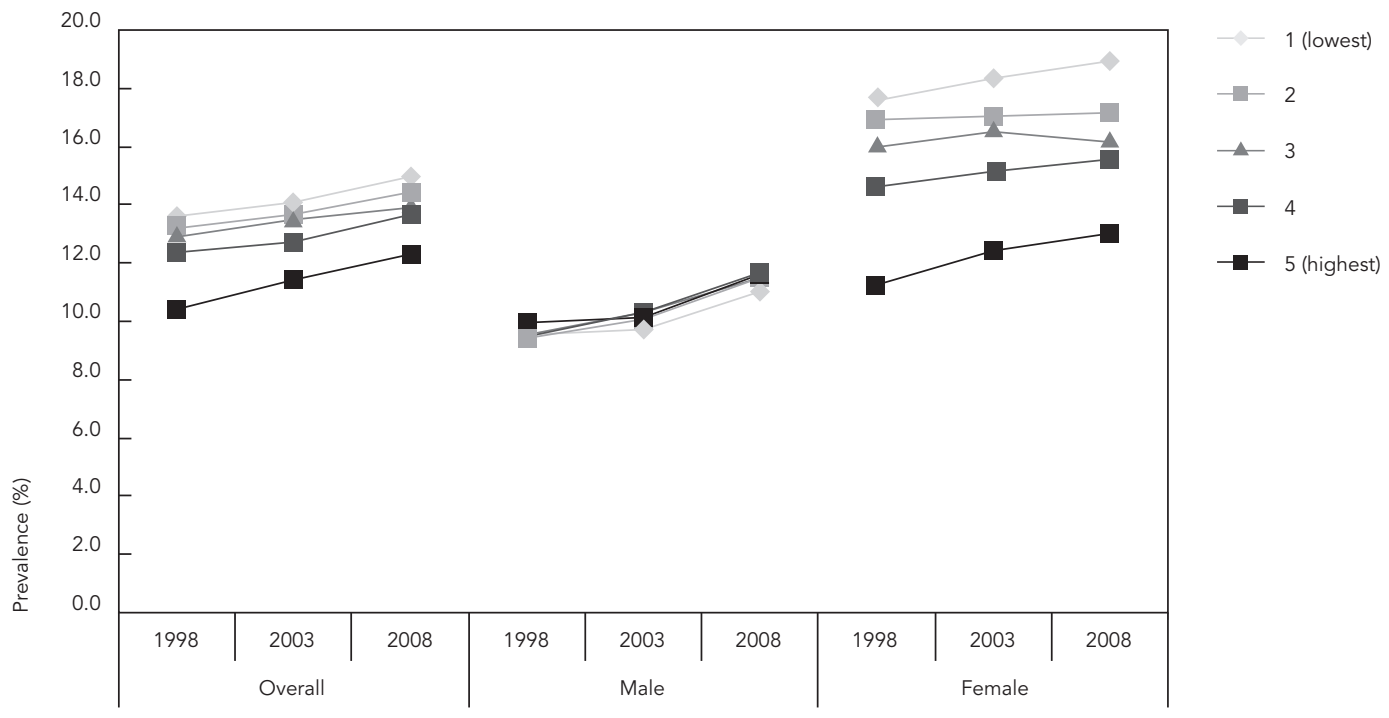


study years was higher among women, the annual increase was higher in men. Self-reported arterial hypertension was proportional to age, and the highest increase was observed in age groups 50 years and older. Higher prevalence rates were also seen in residents of the South and in urban areas of the country.

Nationwide surveys such as the PNAD are useful for understanding the panorama of public health problems such as arterial hypertension, by providing information capable of supporting public policies and strategies for the control of arterial hypertension, thus reinforcing the importance of using such nationwide data and studies 17. The third health supplement of the PNAD allowed verifying a 10-year time trend in self-reported systemic arterial hypertension.

Despite the inherent limitations in obtaining self-reported morbidity data, there is a consensus in the literature that self-reported systemic arterial hypertension is a valid and appropriate indicator for estimating the frequency of the disease, with the advantage of rapid data collection and low cost 13,14,15,16. Another fact to be considered in the utilization of the selfreported measure is the influence of access to health services, such that the prevalence rates may be overestimated.

The current study shows an increase in the prevalence of self-reported arterial hypertension in adults, over the course of 10 years (1998-2008). This finding corroborates other nationwide surveys, many of which in developed countries, using the same measure. However, the variation in definition of age brackets hinders any direct comparison between studies. In Switzerland, the prevalence of self-reported arterial hypertension in individuals 15 years or older increased from $22.1 \%$ to $24.2 \%$ in a 10 -year period 12 . In the United States, self-reported arterial hypertension among individuals 18 years of age and older increased from $68.5 \%$ to $80.6 \%$ between 1988 and $20089,10,11$. Canada showed an increase from $8.2 \%$ in 1994 to $14.6 \%$ in 2005 , among individuals 12 years or older ${ }^{8}$. In Mexico, among individuals 20 to 69 years of age, prevalence of self-reported SAH increased from $23.8 \%$ in 1993 to $43.2 \%$ in 2006 , and in the Czech Republic there was an increase from $41.4 \%$ in 1985 to $68.4 \%$ in 2008 , among participants from 25 to 64 years of age 21 .

In the current study, the prevalence rates for self-reported arterial hypertension were higher among women in all three study years. Other studies on self-reported arterial hypertension have also reported higher prevalence among women 8,9,11,13,14,16,21,22. Some studies that evaluated hypertension using more accurate methods such as repeat blood pressure measurements found a higher prevalence among men 23,24. The current study's findings can be partially explained by women's greater use of health services 25 , which gives them more opportunity to receive a medical diagnosis of arterial hypertension. Another explanation is that obesity $26,27,28$ and physical inactivity are more common among women 29 . However, a larger increase in prevalence, as observed in men, may mean that there is an increase in the risk of cardiovascular diseases in this group. This trend was observed in other studies 6,9,11,21 and may be related to the increase in obesity among men 30 .

Prevalence of self-reported systemic arterial hypertension increased with age, especially after 50 years, which is consistent with other studies showing more frequent reporting of arterial hypertension in older persons $8,9,24,31$. Older individuals tend to use health services more often due to the higher prevalence of disabilities and chronic illnesses in this age bracket. This increases the likelihood that these individuals will receive a medical diagnosis for some disease, like arterial hypertension, which could explain the findings. The current study also showed differences between the regions of Brazil and between areas of residence (urban versus rural). Urban residents presented higher prevalence rates. The relationship between arterial hypertension and urbanization may be associated with increased access to industrialized products by part of the population, lifestyle changes, daily stress ${ }^{32}$, and even greater access to medical services when compared to residents of rural areas of Brazil.

The current study showed a direct relationship between arterial hypertension and socioeconomic status. Travassos et al. 33 demonstrated that in Brazil, access to and utilization of the health system increased in proportion to income and schooling, reflecting the country's pattern of social inequalities, which could explain the finding.

Knowledge on the prevalence of arterial hypertension in Brazil is essential for supporting prevention and control measures that will contribute to reducing the impact of cardiovascular diseases at the population level, especially the subgroups most exposed to the disease. In conclusion, the study showed that overall prevalence of self-reported arterial hypertension increased during the 10-year period. This trend not only reflects increased access to health services, but also exposes the inadequacy of current strategies to fight arterial hypertension. The challenge thus remains to make health promotion and prevention measures more effective, through legislation and regulation, as well as educational activities, 
focusing especially on the reduction of sodium in foods, increased access to and consumption of fruits and vegetables, and treatment of arterial hypertension, among other effective measures.

\section{Resumo}

O estudo avaliou a tendência temporal de hipertensão arterial autorreferida no período de 1998 a 2008, em indivíduos acima de 20 anos, no Brasil. Foram analisados os dados de prevalência de hipertensão da Pesquisa Nacional por Amostra de Domicílios (PNAD) de 1998, 2003 e 2008. A análise considerou a complexidade amostral e incluiu 203.419, 238.591 e 257.816 indivíduos nos anos de 1998, 2003 e 2008, respectivamente. A tendência de hipertensão foi descrita por sexo, renda domiciliar, macrorregiões do Brasil e zona de residência, e as prevalências foram ajustadas por idade. A prevalência de hipertensão foi de 12,5\% em 1998, 13\% em 2003 e 13,9\% em 2008, com incremento anual de 1,07\%. Maior aumento anual ocorreu na Região Sudeste (1,41\%), entre homens (1,82\%) e na zona urbana (1,15\%). Observou-se crescimento nas prevalências de hipertensão em todos os quintis de renda e conforme aumento da idade. Conhecer a abrangência da hipertensão é fundamental para subsidiar ações preventivas e de controle para o problema, sobretudo entre os subgrupos mais expostos.

Hipertensão; Adulto; Doença Crônica; Prevalência

\section{Contributors}

L. C. Muniz was responsible for the literature review, data analysis, and writing of the article. A. M. Cascaes collaborated in the literature review and writing of the article. F. C. Wehrmeister collaborated in the literature review and data analysis. J. Martínez-Mesa collaborated in the literature review and data analysis. A. J. D. Barros oriented the study and revised the article. A. M. B. Menezes oriented the study and conducted the final revision of the article. 


\section{References}

1. Lewington S, Clarke R, Qizilbash N, Peto R, Collins R. Prospective Studies Collaboration. Age-specific relevance of usual blood pressure to vascular mortality: a meta-analysis of individual data for one million adults in 61 prospective studies. Lancet 2002; 360:1903-13.

2. Brundtland GH; from the World Health Organization. Reducing risks to health, promoting healthy life. JAMA 2002; 288:1974.

3. Williams B. The year of arterial hypertension. J Am Coll Cardiol 2006; 48:1698-711.

4. Dib MW, Riera R, Ferraz MB. Estimated annual cost of arterial arterial hypertension treatment in Brazil. Rev Panam Salud Pública 2010; 27:125-31.

5. Trevisol DJ, Moreira LB, Kerkhoff A, Fuchs SC, Fuchs FD. Health-related quality of life and arterial hypertension: a systematic review and meta-analysis of observational studies. J Hypertens 2011; 29:179-88.

6. Villalpando S, Shamah-Levy T, Rojas R, AguilarSalinas CA. Trends for type 2 diabetes and other cardiovascular risk factors in Mexico from 19932006. Salud Pública Mex 2010; 52 Suppl 1:S72-9.

7. Secretaria de Vigilância em Saúde, Ministério da Saúde. VIGITEL Brasil 2009: vigilância de fatores de risco e proteção para doenças crônicas por inquérito telefônico. Brasília: Ministério da Saúde; 2010.

8. Lee DS, Chiu M, Manuel DG, Tu K, Wang X, Austin PC, et al. Trends in risk factors for cardiovascular disease in Canada: temporal, socio-demographic and geographic factors. CMAJ 2009; 181:E55-66.

9. Egan BM, Zhao Y, Axon RN. US trends in prevalence, awareness, treatment, and control of arterial hypertension, 1988-2008. JAMA 2010; 303:2043-50.

10. Yoon SS, Ostchega Y, Louis T. Recent trends in the prevalence of high blood pressure and its treatment and control, 1999-2008. NCHS Data Brief 2010; (48):1-8.

11. Cutler JA, Sorlie PD, Wolz M, Thom T, Fields LE, Roccella EJ. Trends in hypertension prevalence, awareness, treatment, and control rates in United States adults between 1988-1994 and 1999-2004. Hypertension 2008; 52:818-27.

12. Estoppey D, Paccaud F, Vollenweider P, MarquesVidal P. Trends in self-reported prevalence and management of arterial hypertension, hypercholesterolemia and diabetes in Swiss adults, 19972007. BMC Public Health 2011; 11:114.

13. Lima-Costa MF, Peixoto SV, Firmo JO. Validade da hipertensão arterial auto-referida e seus determinantes (Projeto Bambuí). Rev Saúde Pública 2004; 38:637-42.

14. Chrestani MA, Santos IS, Matijasevich AM. Hipertensão arterial sistêmica auto-referida: validação diagnóstica em estudo de base populacional. Cad Saúde Pública 2009; 25:2395-406.

15. Martin LM, Leff M, Calonge N, Garrett C, Nelson DE. Validation of self-reported chronic conditions and health services in a managed care population. Am J Prev Med 2000; 18:215-8.
16. Vargas CM, Burt VL, Gillum RF, Pamuk ER. Validity of self-reported arterial hypertension in the $\mathrm{Na}-$ tional Health and Nutrition Examination Survey III, 1988-1991. Prev Med 1997; 26:678-85.

17. Travassos C, Viacava F, Laguardia J. Os suplementos saúde na Pesquisa Nacional por Amostra de Domicílios (PNAD) no Brasil. Rev Bras Epidemiol 2008; 11 Suppl 1:98-112.

18. Silva PLN, Pessoa DGC, Lila MF. Análise estatística de dados da PNAD: incorporando a estrutura do plano amostral. Ciênc Saúde Coletiva 2002; 7:659-70.

19. Instituto Brasileiro de Geografia e Estatística. Pesquisa Nacional por Amostra de Domicílios: acesso e utilização de serviços, 2003. Rio de Janeiro: Instituto Brasileiro de Geografia e Estatística; 2005.

20. Instituto Brasileiro de Geografia e Estatística. Pesquisa Nacional por Amostra de Domicílios. Rio de Janeiro: Instituto Brasileiro de Geografia e Estatística; 2008.

21. Cifkova R, Skodova Z, Bruthans J, Adamkova V, Jozifova M, Galovcova M, et al. Longitudinal trends in major cardiovascular risk factors in the Czech population between 1985 and 2007/8. Czech MONICA and Czech post-MONICA. Atherosclerosis 2010; 211:676-81.

22. Damasceno A, Azevedo A, Silva-Matos C, Prista A, Diogo D, Lunet N. Hypertension prevalence, awareness, treatment, and control in Mozambique: urban/rural gap during epidemiological transition. Hypertension 2009; 54:77-83.

23. Ford ES. Trends in mortality from all causes and cardiovascular disease among hypertensive and nonhypertensive adults in the United States. Circulation 2011; 123:1737-44.

24. Andersen UO, Jensen GB. Trends and determinant factors for population blood pressure with 25 years of follow-up: results from the Copenhagen City Heart Study. Eur J Cardiovasc Prev Rehabil 2010; 17:655-9.

25. Travassos C, Viacava F, Pinheiro R, Brito A. Utilization of health care services in Brazil: gender, family characteristics, and social status. Rev Panam Salud Pública 2002; 11:365-73.

26. Moura EC, Claro RM. Estimates of obesity trends in Brazil, 2006-2009. Int J Public Health 2011; 57: 127-33.

27. Gigante DP, Moura EC, Sardinha LM. Prevalence of overweight and obesity and associated factors, Brazil, 2006. Rev Saúde Pública 2009; 43 Suppl 2:83-9.

28. Monteiro CA, Conde WL, Castro IR. A tendência cambiante da relação entre escolaridade e risco de obesidade no Brasil (1975-1997). Cad Saúde Pública 2003; 19 Suppl 1:S67-75.

29. Mendonca CP, Anjos LA. Aspectos das práticas alimentares e da atividade física como determinantes do crescimento do sobrepeso/obesidade no Brasil. Cad Saúde Pública 2004; 20:698-709. 
30. Instituto Brasileiro de Geografia e Estatística. Pesquisa de Orçamentos Familiares 2008-2009. Antropometria e estado nutricional de crianças, adolescentes e adultos no Brasil. Rio de Janeiro: Instituto Brasileiro de Geografia e Estatística; 2010.

31. McAlister FA, Wilkins K, Joffres M, Leenen FH, Fodor G, Gee M, et al. Changes in the rates of awareness, treatment and control of arterial hypertension in Canada over the past two decades. CMAJ 2011; 183:1007-13.
32. Ala L, Gill G, Gurgel R, Cuevas L. Evidence for affluence-related arterial hypertension in urban Brazil. J Hum Hypertens 2004; 18:775-9.

33. Travassos C, Oliveira EXG, Viacava F. Desigualdades geográficas e sociais no acesso aos serviços de saúde no Brasil: 1998 e 2003. Ciênc Saúde Coletiva 2006; 11:975-86.

Submitted on $26 /$ Oct/2011

Final version resubmitted on $09 / \mathrm{Feb} / 2012$

Approved on 28/Feb/2012 